\title{
Development of Analogy-Based Material Physics Module to Provide Analogy Ability of Physics Teachers Candidates
}

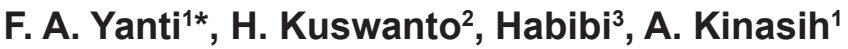 \\ ${ }^{1}$ Faculty of Science and Technology, Universitas Nahdlatul Ulama Lampung, Indonesia \\ ${ }^{2}$ Faculty of Math and Science, Universitas Negeri Yogyakarta, Indonesia \\ ${ }^{3}$ Faculty of Math and Science, IKIP Mataram, Indonesia
}

Received: 1 January 2020. Accepted: 30 March 2020. Published: 30 June 2020

\begin{abstract}
It is known that the 'electronic structure of atoms' in material physics is microscopic. This atomic structure has an abstract and complicated concept, therefore good analogy skills are needed to study comprehensively. This research develops a free analogy-based material physics module to supply analogy skills to prospective physics teacher students. Module development uses the 4D model namely Define, Design, Development and Disseminate. The feasibility aspects are required based on the presentation, content, and grammar. Data obtained from expert assessment and trials using questionnaires, interviews, and tests. Increased student analogy skills were analyzed using normalized N-gain. The results obtained are: (1) the characteristics of the module that has learning steps such as teaching with analogy models, namely: introducing the concept of targets, reviewing the concept of analogies, identifying the relevant nature of targets and analogies, mapping analogies with targets, identifying analogies that are not relevant to targets, and make conclusions, (2) module quality on atomic electronic structure material developed is categorized as feasible, (3) modules are proven to increase mastery of the concept of atomic electronic structure $(\mathrm{N}$-gain $=54 \%$ ) and analytical skills prospective teachers physics $(\mathrm{N}$-gain $=56 \%$ ). The development of physics modules based on free analogies can be applied to other learning, such as biology, chemistry, and mathematics to explain abstract material.
\end{abstract}

Keywords: Free Analogy Methods; Material Physics; Module Development

\section{INTRODUCTION}

Learning in physics education is a learning situation that is engineered by the department to facilitate the prospective physics teacher in storing information provided by lecturers. In essence, physics learning can function as a product, process and attitude. Physics as a product is the result of research by scientists. Physics as a process is the steps used to organize knowledge through observing, classifying, hypothesizing, and concluding activities. Physics as an attitude is a result that arises regarding the scientific activities of students such as honesty, respect for the opinions of others, and curiosity. The concept of physics, especially in advanced physics, discusses many abstract concepts. Therefore, effective and efficient learning methods or strategies are needed so that abstract physics concepts can be under-

${ }^{*}$ Correspondence Address:

Jl. Hanafiah, Mataram Marga, Sukadana, Kabupaten Lampung Timur, Lampung, 34194

E-mail: fitri.aprilyanti@unulampung.ac.id stood properly.

Prospective physics teachers in the fourth semester receive lectures about the electronic structure of atoms. This concept is including a material physics lecture which considered as an abstract concept. The results of interviews in the field indicate that prospective physics teachers tend to have difficulty in understanding the material of electronic atomic structures due to its abstract characteristics. During this time, prospective physics teachers learn through textbooks, but the textbooks have not helped much in overcoming their difficulties in understanding the concept. In general, prospective physics teachers do tend to experience difficulties in understanding abstract material, with learning resources that provide very few illustrations and drawings, and who have to memorize (Knoll, Horton, Krull, \& Dittmar, 2015; Erökten \& Gökharman, 2013; Linsey, Markman, \& Wood, 2012; Mellor, 1968). It appears that prospective physics teachers need physics learning books/modules that are able to portray 
abstract material to be more real. One method that can be used is the analogy method.

The analogy method is a method that can be used to visualize subject matter that is abstract, organizes the learner's thoughts about a meaningful topic, so that learning takes place effectively. A useful method is a method that builds the knowledge of prospective physics teachers and encourages them to actively participate in learning (Chemistry \& Ganesha, 2014; Chan, Paletz, \& Schunn, 2012; Sarikaya, 2007; Walsh, Howard, \& Bowe, 2007). The analogy method is based on the theory of constructivism that connects old knowledge with new one (Stonys, Sapragonas, \& Mockus, 2016; Grandas, 2015; Erdo, 2014; Loc \& Uyen, $2014 ;$ ). The use of analogy designs can be done in a structured way. The analogy method can not only be applied in the form of learning methods, but also can be applied in the preparation of learning modules. Analogy used in learning will shape the knowledge of prospective physics teachers, through the relevance between analogies and targets (Chan et al., 2012; Schiff, 2009; Linsey, Wood, \& Markman, 2008; Linsey, Laux, Clauss, Wood, \& Markman , 2007; Gentner, Holyoak, \& Kokinov, 2001; Money, 1991). Analogy can also be formed spontaneously by giving students freedom in choosing analogies used in learning (Bio, Suardana, \& Kirna, 2014; Chemistry \& Ganesha, 2014; Suja, 2014; Linsey et al., 2008; Chang, Tsai, \& Chen, nd; Cokelez \& Dumon, 2005; Wang, Wang, Kollman, \& Case, 2006; Mizuguchi, Takata, Ikeda, \& Nakashima, 2005). One analogy method that is easy to use is the free analogy method. The free analogy method is a learning method that provides flexibility to choose analogies to be used in learning and does not depend on certain scientific principles (Harrison \& Jong, 2005).

Based on the description that has been delivered, the purpose of this study is to develop a free analogy-based material physics module to equip the analogy abilities of prospective physics teachers.

\section{METHOD}

This research is an Educational Research and Development (R\&D) to produce a free analogy-based learning module on material physics on the concept of atomic electronic structure and test the effectiveness of these products in improving the analogy abilities of prospective physics teachers. This develop- ment research refers to the Thiagarajan model which consists of four stages called the 4D model. The four stages are the stages of define, design, develo, and disseminate. The sample in this study consisted of 20 candidates for physics teachers in the third semester. Data collection instruments in this study used a questionnaire, interview guidelines, and tests.

The define stage is carried out by filling out a questionnaire, interviewing and studying the literature. At the design stage, the draft analogy-based material physics module is freely compiled based on the data define stage, and then tested the validity of content, presentation, and language. The development phase is carried out by testing a small class to correct module readings and a large class test is also conducted to see the response of the prospective physics teacher to the use of the module and the ability of the analogy of prospective teachers. Disseminate stage is the phase of the dissemination of material physics modules based on free analogy on a broader scale as in Fugure 1.

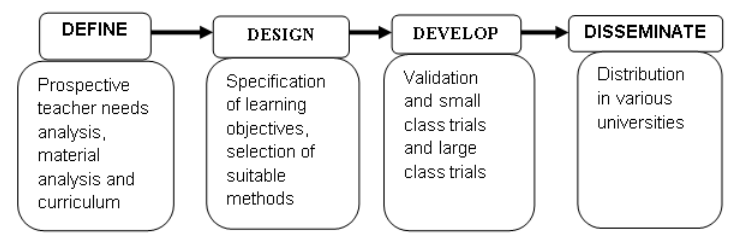

Figure 1. Steps for 4D model

\section{RESULTS AND DISCUSSION}

\section{Stage of Define}

The initial study of the define phase consists of literature study, field studies, and analysis of module design requirements. Field studies conducted with interviews to obtain information about the learning of material physics on the concept of atomic electronic structure. Literature study is carried out by collecting supporting materials related to the free analogy method and the implementation of the free analogy-based material physics lecture module design.

Furthermore, based on the results of the analysis from previous studies, prospective physics teachers still have difficulty in understanding the material of electronic atomic structures (Linsey, Laux, \& Clauss et al, 2007). This is in line with the results of this define stage study which shows that prospective physics teachers need an appropriate method to convey the concept of the electronic structure of atoms 
to their students.

The analogy method is a method used in explaining abstract or microscopic material. This is in line with Prastowo's opinion which revealed that Analogy can help students in understanding the material (Prastowo, 2011). According to him, misconceptions occur because most analogies only explain the relevant things between targets and analogs, without explaining the irrelevance between targets and analogues. Misconceptions can be corrected through an appropriate analogy (Cruz-Hastenreiter, 2015; Devecioglu-Kaymakci, 2016). Based on this opinion, the analogy presented in a learning material needs to pay attention to the steps that are important in composing an analog.

\section{Stage of Design}

This stage is the product design stage in the form of a free analogy based material physics learning module. Modules are based on Surahman (2010) cit. Prastowo (2013) in the structure that contains the least elements: module title, general instructions outlined in basic competencies, subjects, achievement indicators, references, learning strategies that explain the approaches, methods, steps that must be used in the learning process, instructions for physics teacher candidates to understand the steps, learning activity sheets and module materials.

The results of the design phase, a free analogy-based material physics learning module consists of: cover page, Francis page, Preface, table of contents, module position map, glossary, introduction, learning, evaluation, bibliography and answer key. Modules are made in such a way with pictures, examples, exercises and evaluations that serve as supplementary material, and make it easier for prospective teachers to learn the material independently. This module has the following characteristics: the learning steps in the integrated module are free analogy methods, the module can be used to study independently or in groups, the concepts in the module are designed in a simple way so that it makes it easier for prospective teachers to understand concepts. Analogy is displayed at the end of each material discussed.

Instructions for using the module are given to prospective teachers and for lecturers. Prospective teachers are required to study and read sequentially from the beginning to the end, and do each task in the module. As for lecturers, in order to help prospective teachers understand the material in the module. Material preparation that has been done in module compilation is to integrate the free analogy method. The material that is in the module includes: Atomic orbitals, Structure of atoms with many electrons, Bonds in solids, Trend of atoms in the periodic table, and Introduction to energy bonds. The analogy method freely connects analog concepts and targets. The steps in compiling an analogy are as follows: (1) introducing the concept of targets / targets, (2) reviewing analogous concepts, (3) identifying the televant nature of targets and analogues, (4) mapping analogous similarities with targets, (5) identifying analogous properties which is not relevant to the nature of the target, and (6) makes conclusions (Yanti, Kuswanto, \& Mundilarto et al, 2019). The use of visualization through analogies overcomes concerns about students' misconceptions through the lack of a good understanding of the analogy of features that are relevant from analogues to targets (Fathurohman, 2014). Following are examples of sub-chapters on atomic electronic structure material that discuss atomic orbitals in physics modules based on free analogy.

\section{Introducing the target concept}

The target concept used is the energy radiation absorbed by the atoms which causes electrons to move from lower energy (n smaller) to higher energy orbits ( $\mathrm{n}$ larger). Conversely, radiation energy (in the form of photons) is emitted when electrons move from high-energy orbits to lower-energy orbits.

\section{Review the analogy concept}

The concept used as an analogy is the transfer of tennis balls up or down stairs. The ball can be on the stairs to anywhere but not possible in the area between the steps. The step from the lower step to the higher step is a process that requires energy, and vice versa

\section{Identify relevant analogies and targets}

Describing concept of atomic orbit transfer by the transfer concept of tennis balls going up to the stairs.

\section{Mapping anology that is relevant to the tar- get}

Tennis balls function as atoms, while stairs act as atomic orbitals. Identifying analogy that not relevant to the target concept. Analogy: Moving a tennis ball on each stair has the same distance from one stair to the other 
Target: electron transfer, the amount of energy involved in the transfer of electrons from one orbit to another depending on the difference in energy levels from initial to final states.

\section{Conclusion}

Electrons move from lower energy orbits to higher energy. Radiation energy (in the form of photons) is emitted when electrons move from high-energy orbits to lower energy orbits. The amount of energy involved in electron transfer depends on the difference in energy levels from the initial and final states.

\section{Stage of Develop}

The stage begins with the validation of the first draft of the module The results of the validation of the material physics module based on a free analogy before and after a revision are explained in Table 1.

The module revision is based on the validator's suggestion so that a second draft of the module is ready to be tested in a small group of 10 teacher candidates. Module testing is an important part of research and development after the module draft is validated. It aims to determine whether the free analogy-based material physics module that is developed is feasible to use.

Module testing consists of two stages: small class trials and large class trials. The small class trial involved 10 prospective physics teachers to assess the readability which included the writing on the module, the language used, the module helped to understand the material, the completeness of images in the module and the attractiveness of the module.

The results of the readability questionnaire of material physics module based on a free analogy show good categories with some input, among others, there is still a lack of letters in writing words in the module, the location of the image is still incorrect, and there are unclear sentences and have been revised as in Table 2.

Table 2. Revisions after First Trials

\begin{tabular}{ll}
\hline Input & Revision \\
\hline There is an improper & Fixed the images \\
placement of images & placement \\
There are several mi- & $\begin{array}{l}\text { Revise incorrect writ- } \\
\text { ing on the module }\end{array}$ \\
stypes &
\end{tabular}

The results of the small class trial were then revised, so that a third module module which was subsequently tested in a large class was obtained. Large class trials was involving 20 prospective physics teachers in the third semester of 2016. This large class test was

Table 1. Results of Validation and Module Revision

\begin{tabular}{|c|c|c|}
\hline Sources of Validation & Validation Result & Revision \\
\hline \multirow[t]{4}{*}{ Lecturer 1} & $\begin{array}{l}\text { Provide a phenomenon of daily life } \\
\text { in the discussion at the beginning } \\
\text { of the module }\end{array}$ & $\begin{array}{l}\text { The phenomenon of daily life is } \\
\text { given in the discussion at the be- } \\
\text { ginning of the module }\end{array}$ \\
\hline & $\begin{array}{l}\text { Concept maps are adapted to the } \\
\text { rules for making concept maps }\end{array}$ & $\begin{array}{l}\text { Improve the concept map in ac- } \\
\text { cordance with the rules of making } \\
\text { concept maps }\end{array}$ \\
\hline & $\begin{array}{l}\text { The image on the module cover } \\
\text { needs to be removed }\end{array}$ & $\begin{array}{l}\text { Change the module cover image } \\
\text { and discard the image that has } \\
\text { nothing to do with the discussion. }\end{array}$ \\
\hline & $\begin{array}{l}\text { Not yet acknowledged the expert } \\
\text { validator and consultant in the fore- } \\
\text { word. }\end{array}$ & $\begin{array}{l}\text { Give acknowledgment to expert } \\
\text { and consultant validators in the } \\
\text { foreword. }\end{array}$ \\
\hline \multirow[t]{2}{*}{ Lecturer 2} & $\begin{array}{l}\text { There are a lot of repetition of sen- } \\
\text { tences }\end{array}$ & $\begin{array}{l}\text { Improve the module section with } \\
\text { proper sentences. }\end{array}$ \\
\hline & Need exercises questions & Providing excercises question \\
\hline \multirow[t]{2}{*}{ Peers } & $\begin{array}{l}\text { Black and white images on the cov- } \\
\text { er should be replaced with colored } \\
\text { ones }\end{array}$ & $\begin{array}{l}\text { Replace the black and white mod- } \\
\text { ule image on the cover with a col- } \\
\text { ored image }\end{array}$ \\
\hline & $\begin{array}{l}\text { Students should be given space to } \\
\text { answer questions in the experiment }\end{array}$ & $\begin{array}{l}\text { Provide space for students to an- } \\
\text { swer questions }\end{array}$ \\
\hline
\end{tabular}


conducted to determine the effectiveness and response of prospective physics teachers to the use of free analogy-based material physics modules. Classes with analogy-based learning are better in learning outcomes than those in groups that do not use analogy learning (Fikri, Wiyanto, \& Susilo, 2012). This was also similarly expressed by Alvira, Hidayah, \& Chusniah (2016) who stated that the use of analogies in learning facilitates the learning process to be more effective. The results revealed that the material physics module based on free analogies was effectively used in the learning process.

Data on the results of the response, prospective physics teachers agreed to learn using a free analogy-based material physics module. The results of the questionnaire show that the module writing can be read clearly, the completeness of the pictures in the module is good, the module can help understand the subject matter, the module is well packaged, and the language used is easy to understand.

The response of the prospective physics teacher to the free analogy based material physics module stated that $95 \%$ of the physics teacher candidates were happy while participating in the learning activities, $95 \%$ of the physics teacher candidates understood the atomic electronic structure material better, $85 \%$ of the physics teacher candidates stated the free analogy based material physics module could help in learning process, 95\% of prospective physics teachers who learn to use a physics module based on a free analogy, agree that the concept of atomic electronic structures becomes easy, fun, and greatly increase knowledge about analogies, $85 \%$ of prospective physics teachers agree that the modules developed already well.

The ability of the analogy of prospective teachers was analyzed using the gain test to see the difference between the posttest and prettest values and then to determine the increase the $\mathrm{N}$-gain formula was used. The results showed that the average pretest, posttest, gain, and $\mathrm{N}$-gain values are presented in Table 3.

Table 3. Average scores of Pretest, Posttest, Gain, and N-gain analogy abilities of prospective teachers.

\begin{tabular}{llllll}
\hline $\mathrm{N}$ & Pretest & Posttest & gain & $\mathrm{N}$-gain & Categories \\
\hline 20 & 36.00 & 72.22 & 36.22 & 0.49 & Moderate \\
\hline
\end{tabular}

Learning using analogy can improve learning outcomes (Loc \& uyen, 2014). Learning to use analogies can improve conceptual understanding (Dilber, 2012; Toedtanya \& Wuttiprom, 2017). This is in line with the results of analytical ability analysis through a description test in the form of multiple choice questions of 10 questions participated by 20 students. In table 3 shows that the ability of the analogy of prospective teachers in the pretest data is still not good. The low average score of pretest teacher candidates is because the teacher candidates have not been taught in depth the electronic structure of the atom, so that the teacher candidates have difficulty in working on pretest questions. The average posttest score is quite high compared to the average pretest score; this is because prospective teachers have been taught material about the electronic structure of atoms through a free analogybased material physics module.

Research by Alvira, Hidayah, \& Chusniah (2016) shows that understanding analogies will be optimal when the analogies and concepts learned are appropriate. The use of pictorial analogy models is effective for improving student learning outcomes in static electricity and retention occurs either partially (per dimension of knowledge) or as a whole (Djudin \& Grapragasem, 2019; Jonane, 2015). This is evident from the average gain value of student learning outcomes of 36.22 and for the value of $\mathrm{N}$-gain of student learning outcomes of 0.49 in the medium category. Achievement of increasing cognitive learning outcomes of students is not achieved optimally because when working on assignments on the module, some prospective teachers do not follow procedures in determining analogies and concepts. Thus resulting in understanding the analogy of the module there are parts that are less precise.

\section{Stage of Disseminate}

At this stage the distribution was carried out in 3 tertiary institutions which had physics education study programs. The distribution was carried out to the physics lecturer and the respondent questionnaire was given. From the results of the deployment, the lecturer gave an assessment of the development of a free analogy-based material physics module on the concept of atomic electronic structures. The results of the assessment and responses of physics lecturers are included in the excellent category. 


\section{CONCLUSION}

The results showed that the material physics module based on a free analogy consisted of: cover page, francis page, preface, table of contents, module position map, glossary, introduction, learning, evaluation, bibliography and answer key. Modules are made in such a way accompanied by pictures, examples, exercises and evaluations that serve as a complement to the material and make it easier for students to learn the material independently. The free analogy-based material physics module can improve the mastery of the concept of electronic atomic structure $(\mathrm{N}$-gain $=54 \%)$ and can improve the analytical ability $(\mathrm{N}$-gain $=56 \%)$ of physics teacher candidates. Assessment of the prospective teacher's response, $91 \%$ of the respondents agreed that the physics teacher candidates liked to use the material physics module based on a free analogy, easy to learn the material, made it easier to learn, added knowledge, the module was well developed.

Suggestions in this study are intended for prospective physics teachers and other researchers. For prospective physics teachers who will use analogy-based material physics modules, they must first understand the analogies used in the module. This is to avoid misconceptions in understanding material through analogy. For other researchers, the results of this study can be used as a reference for developing similar research, especially research into the development of physics modules. Researchers can develop modules with different learning model characteristics and materials.

\section{REFERENCES}

Alvira, M., Hidayah, N., \& Chusniah, T. (2016). Penerapan Model Analogi untuk Melatih Keterampilan Berpikir Kreatif. Jurnal pendidikan, 758-764.

Bio, B., Suardana, I.N., \& Kirna, I.M. (2014). Analysis of Learning Difficulties of Senior High School Students in Learning Atomic Structure. EJournal Kimia Visvitalis, 2(2), pp.107-116.

Chan, J., Paletz, S.B.F., \& Schunn, C.D. (2012). Analogy as a strategy for supporting complex problem solving under uncertainty. Memory \& cognition, 40(8), pp.1352-65. Available at: http://www.ncbi.nlm.nih.gov/ pubmed/22815065.

Cokelez, A., \& Dumon, A. (2005). Atom and molecule: Upper secondary school French students' representations in long-term memory. Chemistry Education Research and Practice, 6(3), pp.119-135. Available at: https://www. scopus.com/inward/record. uri?eid=2-s2.027544455522\&partnerID $=40 \& \mathrm{md5}=29167 \mathrm{ab}$ c8c146aaea3e7563a9678a9be.

Cruz-Hastenreiter, R. (2015). Analogies in High School Classes on Quantum Physics. Procedia - Social and Behavioral Sciences, 167, 38-43. https://doi.org/10.1016/j.sbspro.2014.12.639

Devecioglu-Kaymakci, Y. (2016). Embedding Analogical Reasoning into 5E Learning Model: A Study of the Solar System. Eurasia Journal of Mathematics, Science and Technology Education, 12(4), 881-911. https://doi. org/10.12973/eurasia.2016.1266a

Dilber, R. (2012). The Effects of Analogy on Students' Understanding of Direct Current Circuits and Attitudes Towards Physics Lessons. European Journal of Educational Research, 1(3), 211-223. https://doi.org/10.12973/eujer.1.3.211

Djudin, T., \& Grapragasem, S. (2019). The Use of Pictorial Analogy to Increase Students' Achievement and Its Retention of Physics Lessons of Direct Current. Jurnal Penelitian Fisika Dan Aplikasinya (JPFA), 9(2), 140. https://doi.org/10.26740/jpfa.v9n2.p140-151

Duit, R. (1991). On the role of analogies and metaphors in learning science. Science Education, 75(6), pp.649-672.

Erdo, R.T. (2014). Teaching Chemical Equilibrium by Analogy- Based Worksheets Teaching Chemical Equilibrium by Analogy-Based Worksheets. Turkish Journal of Teacher Education, 3(September 2016), pp.0-14.

Erökten, S., \& Gökharman, H.K. (2013). The effect of analogy method on student achievement in the unit "the structure and properties of matter" ??ivril sample. World Applied Sciences Journal, 23(6), pp.744-750.

Fathurohman, A. (2014). Analogi dalam pengajaran fisika. Jurnal Inovasi Dan Pembelajaran Fisika, 1(1).

Fikri, K., Wiyanto., \& Susilo. (2012). Penerapan Pembelajaran Fisika dengan Analogi Untuk Meningkatkan Hasil Belajar Siswa SMA. UNNES Physics Education Journal, 1(2252).

Grandas, M. (2015). the Potential of Design-ByAnalogy Methods To Support Product , Service and Product Service Systems Idea Generation. International Conference on Engineering Design, (July), pp.1-12.

Green, K.C., \& Armstrong, J.S. (2007). Structured analogies for forecasting. International Journal of Forecasting, 23(3), pp.365-376.

Jonane, L. (2015). Using Analogies in Teaching Physics: A Study on Latvian Teachers' Views and Experience. Journal of Teacher Education for Sustainability, 17(2), 53-73. https:// doi.org/10.1515/jtes-2015-0011

Harrison, A. G., \& Jong, O. D. (2005). "Using multiple analogies: case study of a chemistry teachers' preparations, presentations and reflec- 
tions". Research and the quality of science education, 353-364. Dordrecht: Springer.

Knoll, S.W., Harton, Graham., \& Krull, Claudia. (2015). Improving the Effectiveness of Ideation Using Analogies: Choosing the Right External Stimuli. Jurnal of Creativity and Business Innovation, 1(JUNE), pp.5-18.

Linsey, J.S., Laux, J., Clauss, E.F., Wood, K.L., \& Markman, A.B. (2007). Effects of Analogous Product Representation on Future Designby-Analogy. Proceeding of the 2007 International Conference on Engineering Design, (August), p.1-13x.

Linsey, J.S., Markman, A.B., \& Wood, K.L. (2012). Design by Analogy: A Study of the WordTree Method for Problem Re-Representation. Journal of Mechanical Design, 134(4), pp.041009-041009.

Linsey, J.S., Wood, K.L., \& Markman, A.B. (2008). Modality and representation in analogy. $A i$ Edam, 22(2), pp.85-100.

Loc, N.P., \& Uyen, B.P. (2014). Using Analogy in Teaching Mathematics: An Investigation of Mathematics Education Students in School of Education - Can Tho University. , 2(7), pp.91-98.

Mellor, D.H. (1968). Models and Analogies in Science: Duhem versus Campbell ? Isis, 59(3), pp.282-290.

Mizuguchi, T., Takata, N., Ikeda, K.I., \& Nakashima,
Hideharu. (2005). Atomic structure and electronic state of $\langle 110\rangle$ symmetric tilt boundaries in palladium. Nippon Kinzoku Gakkaishi/Journal of the Japan Institute of Metals, 69(11), pp.1010-1015.

Prastowo, Andi. (2013). Panduan Kreatif Membuat Bahan Ajar Inovatif. Yogyakarta: DIVA Press.

Prastowo, T. (2011). Strategi Pengajaran Sains dengan Analogi. Jurnal Penelitian Fisika Dan Aplikasinya (JPFA), 1(1), 8-13.

Sarikaya, M. (2007). Prospective teachers' misconceptions about the atomic structure in the context of electrification by friction and an activity in order to remedy them. International Education Journal, 8(1), pp.40-63.

Schiff, R. (2009). Analogical Problem Solving in Children Learning Disabilities. Journal of learning disabilities, 42(1), pp.3-14.

Stonys, A., Sapragonas, J., \& Mockus, S. (2016). The analogy method for the description of external characteristic of inner combustion engines. , 4142(October).

Suja, I. W. (2014). Penggunaan analogi dalam pembelajaran kimia. Jurnal Pendidikan Indonesia, 3(2), pp.397-410.

Suja, I. W. (2014). Strategi "Ermo" Dalam Pengajaran Konsep-Konsep Kimia. Prosiding Seminar Nasional Kimia , ISBN : 978-602-095100-3. Prosiding Seminar Nasional Kimia, (September), pp.16-23. 